\title{
Microtensile bond strength of two self-adhesive cements to enamel and dentin: bonding efficiency and thermocycling effect
}

\section{Microtração de dois cimentos auto-condicionantes (self-adhesive) sobre esmalte e dentina: eficiência de adesão e efeito do envelhecimento}

\author{
Virgílio Vilas Boas FERNANDES JÚNIOR \\ MsC - Restorative Dentistry - School of Dentistry of São José dos Campos - UNESP - Univ Estadual \\ Paulista - São José dos Campos - SP - Brazil.
}

\section{José Roberto RODRIGUES}

Associate Professor - School of Dentistry of São José dos Campos - UNESP - Univ Estadual Paulista - São José dos Campos - SP - Brazil.

\section{João Maurício Ferraz da SILVA}

PhD in Dentistry - Department of Restorative Dentistry - School of Dentistry of São José dos Campos - UNESP - Univ Estadual Paulista - São José dos Campos - SP - Brazil.

\section{Clóvis PAGANI}

Associate Professor - Department of Restorative Dentistry - School of Dentistry of São José dos Campos - UNESP - Univ Estadual Paulista - São José dos Campos - SP - Brazil.

\section{Henderson MALAQUIAS}

DDS - Department of Restorative Dentistry - School of Dentistry of São José dos Campos - UNESP Univ Estadual Paulista - São José dos Campos - SP - Brazil.

\section{Ivan BALDUCCI}

Assistant Professor - Department of Social Dentistry and Pediatric Clinic - School of Dentistry of São José dos Campos UNESP - Univ Estadual Paulista - São José dos Campos - SP - Brazil.

\begin{abstract}
ABSTR ACT
The aim of this in vitro study was to evaluate the bonding efficiency between two self-adhesive cements to enamel and dentine, with and without previous dental surface conditioning, before and after thermocycling. Thirty-six molars were divided into 3 experimental groups and 01 control group. The self-adhesive resin cements selected for the experimental groups were: RelyX Unicem (subgroups RE and RD) and Bifix SE (subgroups BE and BD). For control groups, a conventional resin cement, Variolink II (subgroups VRE and VRD), was used. The specimens were submitted to microtensile bond strength test. The results were submitted to analysis of variance (ANOVA) and Tukey's test. The results showed statistically significant differences between VR group and the others before and after thermocycling. According to the results obtained, it can be concluded that self-adhesive cements, despite of their practicality and less sensitive technique concerning to cementation, have lower adhesive resistance when compared to conventional resin cements.
\end{abstract}

K EYWORDS 


\section{INTRODUCTION}

Restorative Dentistry has been modified in several aspects which seem to institute new rules to the therapeutic modalities of indirect restorations, especially for restorative ceramics $[1,2]$ and resin cements [3-5].

The appearance of dual cure resin cements allowed a significant improving regarding to problems in luting, such as marginal gap, inadequate polymerization of the luting agent, secondary caries and marginal leakage [6-8].

However, these cements demand skilled clinical procedures, especially during the removal of the excess cement prior to its complete polymerization, making this technique a complicated and sensitive procedure [9]. Additionally, to increase the bonding of these cements, it has been recommended the previous conditioning of the tooth surface and restoration.

Aiming to facilitate the use of the technique for resin cements, self-adhesive resin cements have been launched into the market, whose goal is to combine the easy handling of glass ionomer cements with the mechanical, aesthetical and bonding properties of the resin cements [10]. According to the manufacturers, bonding to the tooth occurs without any previous conditioning. This process is based on a new monomer and organic matrix of methacrylatephosphoric acid which etch and infiltrate on tooth surface, contributing to bonding.

Likewise to self-etching adhesive systems, as the self-adhesive cements promote the demineralization of the dentin, the primer and adhesive is impregnated, decreasing the chances of causing a layer of demineralized and non-impregnated dentin. Additionally, problems such as the incomplete removal of the acid after the washing and excessive drying of the dentin do not occur with the use of these systems because the absence of these steps decreases the possibility of post-operative sensibility.

These systems are composed by weak acids which tend to reduce its capacity of etching and bonding to enamel due to the highly inorganic composition of this tissue. In this process, there is the dissolution of the enamel prisms and the enlargement of the interprismatic spaces, allowing the interdiffusion of the resin monomers and the hybridization of the intraand interprismatic enamel instead of the formation of pure resin tags such as those occurring in the systems which employ total etching. In dentin, because of the smallest mineral content, the demineralization and consequent bonding is improved.

Despite of their advantages mainly regarding to their practicality and smaller chair time, self-adhesive cements need further studies on their efficiency regarding to long-term bonding. Therefore, the aim of this study was to evaluate the bonding efficiency between two self-adhesive cements to enamel and dentine, with and without previous dental surface conditioning, before and after thermocycling, through microtensile bond strength test. The null hypothesis was that there would be no statistically significant difference between the self-adhesive cements (Rely $-\mathrm{X}$ and Bifix) and the resin cement (Variolink II) in bond strength.

\section{Material And Methods}

\section{Tooth collection}

Thirty-six sound third molars extracted because of orthodontic reasons, after the approval of the Ethical Committee (\#067/2008-PH/CEP), were selected. The teeth were cleaned and kept in saline solution until their use

\section{Preparation of the Specimens}

For the enamel groups, the buccal surface of 18 third molars was flattened by $600-, 800-$ and $1200-$ grit sandpaper in a polishing machine. The teeth were then divided into three groups according to the cements: RelyX Unicem (RE), Bifix (BE) and Variolink (VRE).

For the dentin groups, the other 18 teeth had their occlusal thirds removed with a diamond disc (Microdont, São Paulo, Brazil, \#34570) at low speed, under refrigeration. Next, the surface was flattened similarly to the aforementioned procedure for the enamel groups. Following, the dentin surface was observed regarding to the presence of enamel and pulp tissues by using an optical microscope and then divided into three groups according to the cements: RelyX Unicem (RD), Bifix (BD) and Variolink (VRD).

Prior to cementation, blocks of direct composite resin (Z1OO, 3M ESPE, St Paul, MN,USA) were light-cured inside a pre-fabricated silicon matrix through small increments of $2 \mathrm{~mm}$ each and the last portion was light-cured after the insertion of a polyester strip to promote a flat and smooth surface.

The composition of the resin cements are described in Chart 1. 


\section{Chart 1 - Resin Cements AND their composition}

\begin{tabular}{l|l|l|l}
\hline $\begin{array}{l}\text { Variolink } \\
\text { II }\end{array}$ & $\begin{array}{l}\text { Dual } \\
\text { cure }\end{array}$ & $\begin{array}{l}\text { Ivoclar } \\
\text { Vivadent }\end{array}$ & $\begin{array}{l}\text { BisGMA/UDMA/TEGDMA/ } \\
\text { DMA/barium sulphate/Ba- } \\
\text { Al-F-Si-glass/silica, Benzoyl } \\
\text { peroxide glycerin }\end{array}$ \\
\hline $\begin{array}{l}\text { Rely-X } \\
\text { U-CEM }\end{array}$ & $\begin{array}{l}\text { Self- } \\
\text { adhesive }\end{array}$ & $\begin{array}{l}\text { EMPE } \\
\text { ESPE }\end{array}$ & $\begin{array}{l}\text { glass powder, silica, calcium } \\
\text { hydroxide, pigments, pyridine } \\
\text { peroxide, methacrylate } \\
\text { phosphoric acid ester, } \\
\text { dimethacrylate, acetate, } \\
\text { stabilizer, initiator, acetate. }\end{array}$ \\
\hline Maxcem & $\begin{array}{l}\text { Self- } \\
\text { adhesive }\end{array}$ & $\begin{array}{l}\text { Kerr } \\
\text { Hawe } \\
\text { Neos } \\
\text { Orange }\end{array}$ & $\begin{array}{l}\text { Resin matrix: self-adhesive } \\
\text { acid monomer (GPDM), } \\
\text { co-monomers, self-curing } \\
\text { initiators, photoinitiator, } \\
\text { stabilizer. } \\
\text { Inorganic matrix: } 67 \% \text { vol. }\end{array}$ \\
\hline
\end{tabular}

\section{Cementation}

For the groups RE, BE, RD, BD, The cements RelyX Unicem (3M ESPE/ St. Paul, MN, EUA) and Bifix SE (Voco/GHBM, Germany) were mixed according to the manufacturers' instructions and directly applied onto the tooth surface without any previous conditioning. The blocks of composite resin were then positioned and locked by a standardized load by a mobile spindle. Following, the excesses were removed and the set (toothcement-block) was light-cured for 40 seconds (light-cure unit XL 3000, 3M ESPE, MN, USA; $500 \mathrm{~mW} / \mathrm{cm} 2$ ) on each side of the interface cement/ tooth surface.

For the groups VRE and VRD, twelve teeth received a conditioning by $35 \%$ phosphoric acid for $30 \mathrm{~s}$ and $15 \mathrm{~s}$, respectively, followed by the copious rinsing with air/water jet for $10 \mathrm{~s}$ and application of the bonding agent (Adper Single Bond 2, 3M/Espe, St. Paul, Mn, USA), following the manufacturer's instruction. The cement (Variolink II) was mixed at 1:1 proportion, for 10 seconds. Then, it was applied onto the tooth surface and the resin block was placed following the same procedure for the other groups. After 24 hours of storage in distilled water at 37OC, the samples (resin block/tooth) were sectioned perpendicularly to the interface cement/tooth, in a cutting machine (LabCut 1010, Extec, Enfield, CT, USA) by using diamond discs (Microdont, São Paulo, Brazil, \#34570), at low speed, under copious irrigation. The samples were placed in order that the interface cement/tooth is perpendicularly to the diamond disc of the machine. The first cut, measuring about $1 \mathrm{~mm}$, was discarded to standardize the samples. Next, other three sections measuring $1.0 \mathrm{~mm}$ thick were prepared.
After that, the fixation device of the samples was rotated at 90 degrees, and other four cuts were performed similarly to the aforementioned procedure. In average, nine rectangular specimens with $1.0 \mathrm{~mm} 2$ and $8 \mathrm{~mm}$ length were obtained.

Half of the samples were analyzed just after the cuts and the other half was submitted to thermocycling $\left(5,000\right.$ cycles; $5^{\circ} \mathrm{C} / 55^{\circ} \mathrm{C}$, time period: $30 \mathrm{~s}$, transference time: $2 \mathrm{~s}$ ) (Nova Etica, São Paulo, Brazil).

\section{Microtensile bond strength test}

The samples were individually fixed by their endings with a cyanoacrylate gel adhesive (Super Bonder Gel, Loctite Ltd, Piracicaba, SP, Brazil), in the microtensile bond strength machine (LA 2500, Erios, São Paulo, SP, Brazil), by placing the bonding area perpendicular to the long axis of the bond strength, therefore avoiding the occurrence of torsion and shear forces (Figure 1).

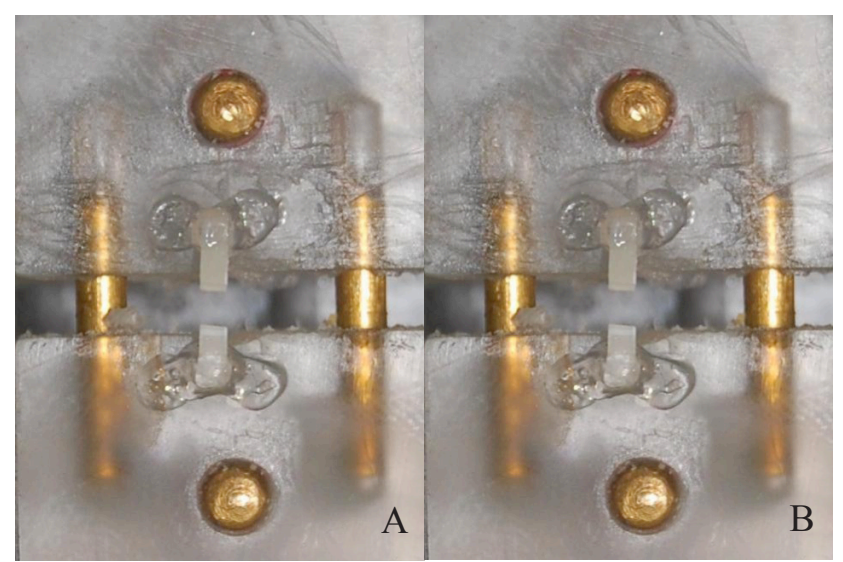

Figure 1 - Sample positioned in the machine, before $(A)$ and after $(B)$ the test.

The test was performed at constant speed of $1 \mathrm{~mm} /$ min in a universal testing machine (DL200 MF, Emic, São José dos Pinhais, Paraná, Brazil), with load of $10 \mathrm{Kg}$. At the moment of the fracture, the movement was automatically stopped and the microtensile bond strength values were recorded and tabulated for statistical analysis.

At the ending of the test, the two parts of the sample were stored to enable that the fracture pattern be evaluated.

\section{Statistical analysis}

Three-way ANOVA and Tukey test for multiple comparisons were applied for statistical analysis, 
considering the following factors: resin cement, thermocycling, and tooth substrate. The level of significance was set at $5 \%$ for all tests.

\section{Results}

The statistical analysis was carried out comparing the effects: cement, cement $\mathrm{x}$ area, cement $\mathrm{x}$ thermocycling and cement $\mathrm{x}$ area $\mathrm{x}$ thermocycling. There was a statistically significant difference in the interaction cement $\mathrm{x}$ area $\mathrm{x}$ thermocycling. Means and standard deviation can be analyzed in Graph 1.

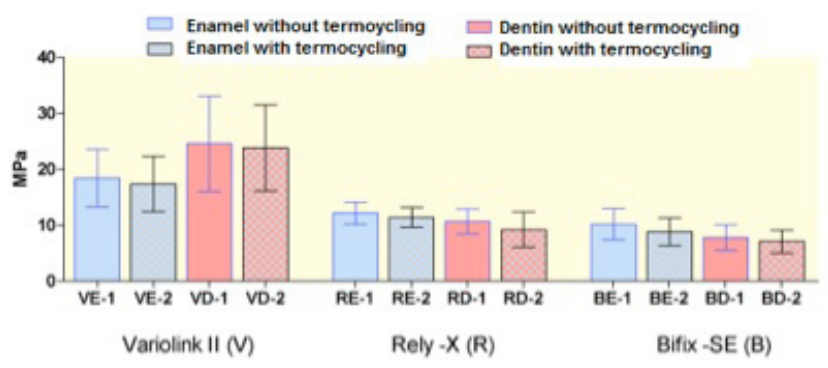

Graph 1 - Column Graph (mean \pm standard deviation) of the values obtained in the microtensile bond strength test in $\mathrm{MPa}$, according to the experimental conditions.

Considering the statistical difference, Tukey test for multiple comparisons was applied with level of significance set at 5\%. There was statistically significant difference among Variolink (both for enamel and dentin) and the other groups before (VE: 18,411) (VD: 24,574) and after thermocycling (VE: 17,350) (VD: 23,800).

There was no statistically significant difference between the self-adhesive cements, except between groups RE and BD; (RE: 12,107 and 11,400), (RD: 11,400 and 9,196), (BE: 10,132 and 8,815), (BD: 7,752 and 7,077). The means and the homogenous groups can be verified in tables 1 and 2 .

TABLE 1 - Homogenous groups Without THERMOCYCLING

\begin{tabular}{c|c|c|c}
\hline Cement & $\begin{array}{c}\text { Tooth } \\
\text { substrate }\end{array}$ & Mean & $\begin{array}{c}\text { Homogeneous } \\
\text { Group }\end{array}$ \\
\hline VR & D & 24,574 & A \\
\hline VR & E & 18,411 & B \\
\hline R & E & 12,107 & C \\
\hline R & D & 10,640 & CD \\
\hline B & E & 10,132 & CD \\
\hline B & D & 7,752 & D \\
\hline
\end{tabular}

\section{TABLE 2 - Homogenous groups With} THERMOCYCLING

\begin{tabular}{c|c|c|c}
\hline Cement & $\begin{array}{c}\text { Tooth } \\
\text { substrate }\end{array}$ & Mean & $\begin{array}{c}\text { Homogeneous } \\
\text { Group }\end{array}$ \\
\hline VR & D & 23,800 & A \\
\hline VR & E & 17,350 & B \\
\hline R & E & 11,400 & C \\
\hline R & D & 9,196 & CD \\
\hline B & E & 8,815 & CD \\
\hline B & D & 7,077 & D \\
\hline
\end{tabular}

The analysis of the surface fracture demonstrated for the experimental groups (Rely-X and Bifix SE), predominantly adhesive failures; in control group (Variolink II), the failures were predominantly mixed.

\section{Discussion}

During the cementation of an indirect restoration, the luting agent is placed between the tooth and the restoration, creating two distinct interfaces: restoration/cement and cement/tooth surface. Resin cements are the materials of choice for indirect cementation, mainly in cases of metal-free crowns $[10,11]$. The bonding between the resin cements and the indirect restorations is not a great concern in clinical practice because surface conditioning has been indicated to increase this bonding $[12,13]$. On the other hand, the bonding between the tooth substrate and the resin cement, required for the durability of the tooth/restoration system $[10,11,14,15]$, has been the most critical and difficult step. In order to achieve a proper bonding, surfaces conditioning, such as total acid etching or the use of self-adhesive cements has been commonly used [16-18].

In our study, the hypothesis that the application of the experimental cements (Rely-X and Bifix) through their simplified mode as indicated by their manufacturers would not decrease the bond strength in comparison with the conventional cements (here represented by the control group) was not proved because the results showed that there was a significant difference between them, both in enamel and dentin, before and after thermocycling.

This was proved by the highest bonding values of the surfaces conditioned by phosphoric acid followed by the application of the bonding system (control group) in comparison with those obtained by the experimental groups (self-adhesive cements). Also, in this present study, several samples of the experimental groups showed spontaneous failure during the cutting 
procedures, suggesting low shear bond strength. Acid etching creates microporosities on the interprismatic enamel through where the hydrophobic monomers of the bonding agent may penetrate originating high micromechanical retention [14]. These results are in agreement with those of other studies $[16,19,20]$ which demonstrated that the surface conditioning prior to the application of the resin cement resulted in high bond strength in comparison with non treated substrates. The replacement of the acid phosphoric etching by the acid monomers present in the selfadhesive cements promotes a low interprismatic hybridization and, consequently, a weak bonding $[16,17,19,20]$. This may explain the similar results of the experimental groups, which demonstrated that despite of the low $\mathrm{pH}$ of these cements (around 2 at the first minute), an apparent demineralization of the tooth surface did not occur. According to De Munck et al [16], this is because of the high viscosity of these materials with consequent deficiency of penetration in function of the time. De Angelis et al [21] reported that Rely-X Unicem showed the smallest number of pre-test failures in relation to the other self-adhesive cements (iCEM - Heraeus Kulzer, Maxcem - Kerr, Enacem HF - Micerium). The authors also reported that this cement did not show statistically significant difference in relation to the other self-adhesive cements, although it still presented statistically smaller bond strength than the conventional multiple step cements (Panavia F - Kuraray).

Concerning to bonding to dentin, De Munck et al. [16] reported that Rely-X Unicem, applied in a simpler way showed a bond strength similar to control group (Panavia F). In other study, Sahar et al.
[22] obtained results without statistically significant difference among Rely-X Unicem and Panavia F, Variolink, Dyract Cem Plus; and results significantly higher than Ketac Cem prior to thermocycling. After thermocycling, the authors also reported the increasing in the bond strength, statistically higher than Panavia F, Dyract Cem Plus and Ketac Cem, although smaller than Variolink. This is because of the highest sensibility of the self-adhesive cements without water as solvent [2] and to the possible acidbase reaction occurring among the acid monomers of the bonding agents, especially those of Dyract Cem Plus, inhibiting the initiation of the chemical curing components of the cements [19].

In our study, we observed that Variolink also presented a significantly higher bond strength than the other self-adhesive cements, which was partially in agreement with the results of a previous study [22], because after thermocycling the bonding values of Rely-X did not increase, according to the author. In this study, the thermocycling did not promote a significant reduction in the bond strength values of all groups. Based on the results of this study, further studies are necessary to explain the interaction between self-adhesive cements and tooth substrate, especially regarding to demineralization and impregnation of the resin monomers and consequently to bond strength.

\section{Conclusion}

Self-adhesive cements, despite of their practicability, do not show yet bond strength values similar to conventional resin cements.

\begin{abstract}
Resumo
O objetivo deste trabalho foi analisar in vitro a eficiência de adesão através de ensaio de microtração, de dois cimentos autocondicionantes (self-adhesive), sobre esmalte e dentina, antes e após termociclagem em comparação a um cimento resinoso convencional. Foram utilizados 36 terceiros molares, separados em grupos experimentais, sendo 2 grupos com cimentos resinosos auto-condicionantes (Rely X Unicem - 3M ESPE - subgrupos RE e RD) e Bifix SE - Voco/GHB subgrupos BE e BD) e 1 grupo controle, com o cimento adesivo (Variolink II - Ivoclair - subgrupo VRE e VRD). Para a análise estatística do teste de adesão, foi utilizado ANOVA 3 fatores com teste de comparação múltipla de Tukey (5\%). Os resultados evidenciaram diferença significante entre os grupos VR, dos demais grupos, antes e após termociclagem. De acordo com os resultados, podemos concluir que os cimentos autocondicionantes, apesar da sua praticidade, facilidade de técnica e menor susceptibilidade de hidrólise, ainda possuem menor resistência adesiva em relação aos cimentos resinosos convencionais.
\end{abstract}

\title{
Palavras-chave
}




\section{References}

1. Conrad HJ, Seong W, Pesun IP. Current ceramic materials and systems with clinical recommendations: a systematic review. J Prosthet Dent. 2007;98(5):389-404.

2. Frankenberger R, Kramer N, Petschelt A. Technique sensitivity of dentin bonding: effect of application mistakes on bond strength and marginal adaptation. Oper Dent 2008;25(4):324-30.

3. Bouillaguet S, Troesh S, Wataha JC, Krejci I, Meyer JM, Pashley DH. Microtensile bond strength between adhesive cements and root canal dentin. Dent Mater 2003;19(3):199205.

4. Kumbuloglu O, Lassila LVJ, User A, Toksavul S, Vallittu PK. Shear bond strength of composite resin cements to lithium disilicate ceramics. J Oral Rehabil. 2005;32(2):128-33.

5. Pameijer $\mathrm{CH}$, Stanley HR. Primate pulpal response to anhydorus Chembond. J Dent Res.1984;63(5):171.

6. Cardash HS, Baharav H, Pilo R, Bem-Amar A. The effect of porcelain color on the hardness of luting composite resin cement. J Prosthet Dent. 1993;69(6):620-3.

7. EL-Badrawy WA, EL-Mowafy OM. Chemical versus dual curing of resin inlay cements. J Prosthet Dent. 1995;73(6):515-24.

8. Isidor F, Brondum K. A clinical evaluation of porcelain inlays. J Prosthet Dent. 1995;74(2):140-4.

9. Bouillaguet S, Degrange M, Cattani M, Godin C, Meyer JM. Bonding to dentin achieved by general practitioners. Schweiz Monatsschr Zahnmed. 2002;112(1):1006-11.

10. Piwowarczyk A, Bender R, Ottl P, Lauer HC. Long-term bond between dual-polymerizing cementing agents and human hard dental tissue. Dent Mater 2007;23(2):211-7.

11. De Munck J, Van Landuyt K, Peumans M, Poitevin A, Lambrechts $\mathrm{P}, \mathrm{Braem} \mathrm{M}$, et al. A critical review of the durability of adhesion to tooth tissue: methods and results. J Dent Res 2005;84(2):118-32.

12. Ellakwa AE, Shortall ACC, Burke FJT, Marquis PM. Effects of grit blasting and silanization on bond strengths of a resin luting cement to Belleglass HP indirect composite. Am J Dent 2003;16(1):53-7.

13. El Zohairy AA, De Gee AJ, Mohsen MM, Feilzer AJ. Microtensile bond strength testing of luting cements to prefabricated CAD/CAM ceramic and composite blocks. Dent Mater 2003;19(3):575-83.

14. Miyazaki M, Sato M, Onose H. Durability of enamel bond strength of simplified bonding systems. Oper Dent 2000;25(2):75-80.

15. Piwowarczyk A, Lauer HC, Sorensen JA. In vitro shear bond strength of cementing agents to fixed prosthodontic restorative materials. J Prosthet Dent 2004;92(3):265-73.

16. De Munck J, Vargas M, Landuyt K V, Hikita K, Lambrechts P, Meerbeek B V. Bonding of an auto-adhesive luting material to enamel and dentin. Dent Mater 2004; 20(10);963-71.

17. Duarte S, Botta AC, Meire M, Sadan A. Microtensile bond strengths and scanning electron microscopic evaluation of self-adhesive and self-etch resin cements to intact and etched enamel. J Prosthet Dent 2008;100(3):203-10.

18. Van Landuyt KL, Peumans M, De Munck J, Lambrechts P, Van Meerbeek B. Extension of a one-step self-etch adhesive into a multi-step adhesive. Dent Mater 2006;22(6):533-44

19. Hikita K, Van Meerbeek B, De Munck J, Ikeda T, Van Landuyt $\mathrm{K}$, Maida $\mathrm{T}$, et al. Bonding effectiveness of adhesive luting agents to enamel and dentin. Dent Mater 2007;23(1);71-80.
20. Swift EJ, Perdigao J, Heymann HO. Bonding to enamel and dentin: a brief history and state of the art. Quintessence Int 1995;26(2);95-110.

21. De Angelis F, Minnoni A, Vitalone LM, Carluccio F, Vadini $\mathrm{M}$, Paolantonio $\mathrm{M}$, et al. Bond strength evaluation of three self-adhesive luting systems used for cementing composite and porcelain. Oper Dent. 2011;36(6):626-34.

22. Sahar E, Hamar A, Hiller KA, Jung H, Federlin M, Friedl $\mathrm{KH}$, et al. Bond strength of a new universal self-adhesive resin luting cement to dentin and enamel. Clin Oral Investig. 2005;9(3):161-7.

Received: $16 / 07 / 2011$

Accepted: 23/02/2012

Corresponding author:

Virgílio Vilas Boas Fernandes Júnior

Rua Enseada , 46 - Cidade Jardim

São José dos Campos - SP - Brasil. - CEP: 12230-630 virgiliovilas@hotmail.com 